he gave expression to the satisfaction this recognition affurded him.

Beyond this magnificent work and those papers more or less immediately associated with it, wholly taxonomic, Sladen produced others of a physiological and developmental order, as for example his Naples Station paper, on the structure and functions of the pedicellarix, and that announcing his discovery of the "cribriform organ" and his papers on the apical plates of the Astrophiuroids, in which he was obviously in agreement with his friend, the late Dr. Herbert Carpenter, in the belief in a stalked ancestry of these. It has been said of his taxonomic work that his descriptions are protracted, and that he deals with specimens as species. There is, however, no reason to believe that he was using the term species in any but a purely conventional sense, without necessarily implying any fixed inter-relationships ; and his painstaking accuracy of description was the outcome of an excessive honesty of purpose and desire for thoroughness, in which he was altogether exemplary. There never lived a man with a truer sense of honour.

Some ten years ago Sladen had a bad attack of influenza, followed at intervals by several similar visitations, which unfitted him for serious scientific work, but he always hoped to get better and to take it up again. The last winter was passed in Devonshire with very beneficial results, and he might be said to have been in his usual health when two months ago he started with his wife for Rome. But the wish to return to work was not to be fulfilled; after spending six weeks in Rome he journeyed to Florence, and there after a week of rather active sightseeing, on June II, he was taken with a fainting fit, and though he quickly recovered consciousness and declared his intention of going to Como that very night, within half an hour he passed away by failure of the heart's action.

He was a Fellow of the Linnean, Zoological, and Geological Societies; for ten years Zoolngic Secretary, and later a VicePresident of the former. In his secretarial capacity his genial nature found full sway, and his encouraging attitude to the younger men with whom he came in contact will ever be remembered. As a boy at school he was the captain wrestler. He was a good shot, though never a sportsman or member of a rifle corps, but he belonged to a private Guerilla Club in Yorkshire, of which he was sometime secretary.

In I890 Sladen married Constance, elder daughter of the late Dr. W. C. Anderson, of York; and about two years ago he inherited from an uncle the estate of Northbrook, near Exeter, and there he has been laid to rest. It will be remembered that he recently gave the sum of $2000 l$. to insure the lives of the Yeomanry and Volunteers of his county going to the front in the Boer campaign; and this is but one among many of his generous acts, the majority of which are known only to the recipients. A loving husband, a trustworthy friend, whose advice was always sound, a keen sympathiser with suffering humanity, he has passed from us; but his memory and tender-loving influence for good will endure.

Among his scientific effects are a large library and some zoological collections of great value. Sladen had always a taste for old books, and one of his last expeditions was to a monastery at Subiaco, to examine some ninth century MSS. there preserved, and he had collected a goodly number of ancient MSS. and examples of early printing. His collection of Echinoderm literature is very complete ; while, as to material, he leaves the collections of his friend, the late Herbert Carpenter, rich in Crinoids and other rare animal forms, which include, as a separate historic possession, the materials which formed the basis of the elder Carpenter's book on the microscope. These he purchased. There were also in his possession at the time of death a large series of Cretaceous Echinoderms, upon which he was contemplating a renewal of his Palæontographical Society's work; and the collection of Astrophiuroids of the Albatross, entrusted to his hands by Prof. A. Agassiz. There accompanied these a series of superb coloured drawings from the life, like those already published for the Holothuroidea of the expedition; and the very day of his death there reached him a letter from the same distinguished explorer, offering him the materials of his recent Australian cruise. It was Sladen's intention to have returned to these rich possessions; and we could desire no more fitting memorial to his work than that it might be possible to find and train a competent zoologist to continue that which he has left thus unfinished, on the lines on which he would have laboured, and to hand it down to posterity a completed record in his name.

G. B. H.

\section{JEREMIAH HORROCKS AND THE TRANSIT} OF VENUS.

WE are indebted to the Journa' of the Leeds Astronomical Society for I899, which contains an interesting paper by Mr. A. Dodgson, on the life and work of the illustrious young astronomer, Jeremiah Horrocks. This worthy was born in I6I9, 28I years ago, in the reign of James I., at Toxteth, three miles from Liverpool. He received his early education there, but on reaching the age of fourteen, he entered as "sizar" at Emmanuel College, Cambridge. At seventeen he was enabled to become tutor at Toxteth, and two years later, i.e. in his nineteenth year, he was appointed curate at Hoole, near Preston. Soon after this he made his memorable astronomical observation of Venus, and only two years later was dead. The life of the young man at Cambridge, as traced by Mr. Dodgson, was one of persistent industry. Imbued at an early age with a love of studying natural phenomena, he was hampered at the outset

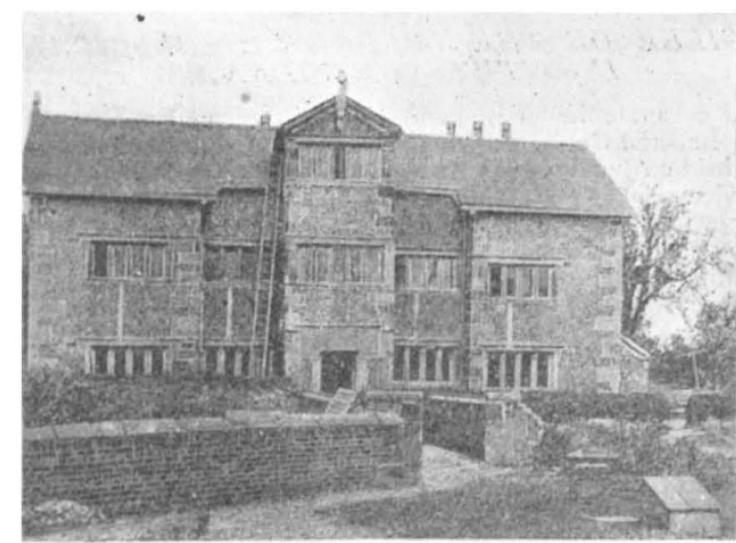

Venus in sole visa. Nov. 24, 1639.

IN MEMOEY OP

JELEMIYAI HORROX, ONE OF THZ ERDATF.T

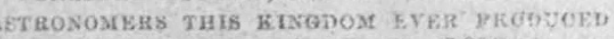
BOKN IN TOXTETH PARK IN 1619 DIED IN 1641, A'CEX 22

HIS OBSBRVATIONS WERE MADE AT HOOJE, LHGHT MILES FROX PRESTON, WHERE TE PREDICTED, AND WAS THB FTRST PERSON WHO SAW, THE TRANSIT OF VENUS OVER THE SUN.

THIS MONUMENT WAS ERECTED BY H. HOLDEN, ASTRONOMER 1826.

by the absence of instruction in mathematics and the scarcity of books. This difficulty of getting philosophical and scientific works is clearly shown by the fact that of the thirty-two volumes he possessed later, not one was published in England or written by an Englishman. Lansberg's works he could not make agree with his own observations, and later, having obtained those of Kepler through the advice of his friend Crabtree, of Manchester, he found that even they needed many corrections. His first results in astronomical research were in elucidation of the lunar theory. Sir Isaac Newton confirms that he was the first to state the ellipticity of the moon's orbit; he also stated the causes of "evection " and " annual equation." The experiment of the circular pendulum for illustrating the action of a central force is also due to him. Most interesting, however, is his successful prediction of the transit of Venus in November, 1639. Kepler had stated that the two next transits would occur in 1631 and $176 \mathrm{r}$, but Horrocks found, during his revision of the tables he had in use, that another would take place, the slight

NO. 1602, vOL. 62] 
errors in Kepler's tables probably accounting for his omitting it. Horrocks made all preparations for observing the phenomenon, arranging the image projected from his telescope (which had cost him half-a-crown) on a sheet of white paper having a circle six inches in diameter traced on it, the circumference being divided into degrees. He watched from sunrise to nine o'clock, and from ten until noon. Resuming his labour again shortly after three, he was overjoyed to find a round black spot just within the limb of the sun, at the internal contact. During some thirty minutes he was enabled to make many observations, which he considered very successful. Besides these definite scientific achievements, he wrote upon many different phenomena connected with the solar system, including the motions of Jupiter, Saturn, and various comets. The illustration on p. 257, reproduced from Mr. Dodgson's paper, shows Carr's house at Hoole, where Horrocks made his transit observation, and also the monu mental tablet erected in 1826 to his memory in Hoole Church.

\section{IUBILEE OF THE IMPERIAL GEOLOGICAL INSTITUTE OF VIENNA.}

TO celebrate the fiftieth anniversary of the foundation of the Imperial Geological Institute of Vienna, a jubilee meeting was held on June 9 in the Great Hall of the Institute under the presidency of its present director, Hofrath Guido Stache. The meeting was attended by a number of high Government officials, geologists, and representatives of national industries and scientific associations.

The director having welcomed the guests, speeches of congratulation were delivered by his Excellency the Minister for Spiritual and Educational Affairs, Dr. W. Ritter von Hartel, his Excellency the Minister for Railways, Dr. H. Ritter von Wittek, and the Mayor of Vienna, Dr. C. Lueger. These were succeeded by the following representatives of scientific institutions and industries, who presented addresses : Geheimrath von Richthofen, conveying the good wishes of the Prussian Royal Academy of Sciences, the Gesellschaft fuir Erdkunde, and the German Geological Society ; Prof. Dr. Beyschlag, for the Royal Prussian Geological Institution and the Berg Akademie of Berlin; Geheimrath Dr. Lepsius, for the Grandducal Institute of Hesse and the Upper Rhine Geological Society at Darmstadt ; Prof. Dr. E. Naumann, for the Senckenberg Natural Science Society of Frankfurt a-M. ; Sectionsrath Boeck, for the Hungarian Geological Institution and the Hungarian Geological Society ; and Chief Geologist Pethö, for the Natural Science Association of Buda-Pesth.

Among Austrian representatives there were: Prof. E. Suess, as President of the Imperial Academy of Sciences; Prof. L. Szajnocha, for the Cracow Academy ; Prof. Woldrich, for the Bohemian Francis Joseph Academy; Hofrath Steindachner, for the Court Museum of Natural History; his Excellency FieldMarshal Ritter von Steeb, as Commandant of the Military Geographical Institute ; Rector Zeisel, for the Agricultura College ; Hofrath Juraschek, for the Central Statistical Commission; Prof. Doelter, for the Steiermark Scientific Society; and Vice-President Straberger, for the Francisco-Carolineum at Linz.

The good wishes of the Lower Austrian Chamber of Commerce were presented by the President of the Northern Railway, Hofrath Jeitteles, and the congratulations of societies for the advancement of allied sciences were tendered by Custos Marenzeller, Freiherr von Puche, Hofrath Toula, Freiherr von Andrian, and Councillor Karrer. In conclusion, the Chairman read those parts of the Jubilee Report which referred to the advancement of the Institute by the Emperor and the Government.

Among the 264 messages of congratulation received the following are specially mentioned : from the Geological Survey of Great Britain and Ireland, the Geological Society and the Iron and Steel Institute in London, the Smithsonian Institution and the United States Coast and Geodetic Survey in Washington, the American Philosophical Society in Philadelphia, and the Cincinnati Society of Natural History. Also those of the Imperial Russian Academy of Sciences, the Russian Geological Committee, and the Imperial Russian Mineralogical Society at St. Petersburg ; the Naturalists' Society of Moscow, the Royal Swedish Academies at Stockholm and Upsala, the Academia dei Lincei and the Ufficio Geologico in Rome, the Science NO. 1602 , vOL. 62
Academies of Naples and Turin, the Belgian Geological Society the Royal Academy of Amsterdam, and scientific associations and institutions at Hallé, Dresden, Leipzig, Breslau and Göttingen.

The Institute, or Geologische Reichsanstalt, was founded in I 849 by the then Minister of Mines and Agriculture, von Thinnfeld, with the object of working out the geology of the whole empire, collecting and arranging the material, and publishing the results in maps and memoirs. Haidinger was its first director, and his chief geologist was Freiherr von Hauer, who was appointed director on Haidinger's death in 1866 . In those early days the position of the Institute was not by any means secure. In I859 an attempt was made to abolish it as a separate institution and to incorporate it with the mathematical and natural science section of the Imperial Academy of Sciences. But the proposed change failed to obtain the approval of the Reichsrath

Between I867 and I87I, under von Hauer's direction, a geological map of the Austro-Hungarian Monarchy was published, to a scale of $I$ in 576,000 . Under the supervision of the present director, Hofrath G. Stache, the publication of a series of detail maps has been commenced. The publications of the Institute comprise the annual Jahrbuch, which has now reached its fiftieth volume, the Verhandlungen, and the Abhandlungen. The latter are in 4to, and up to the present they have an aggregate of 7000 pages and 950 lithographic plates. Besides, explanatory letterpress is issued with each section of the new detailed geological map drawn to a scale of $I$ in 75,000 .

A chemical laboratory is attached to the Institute, which undertakes geological and industrial analyses. This laboratory was suppressed for several years, owing, it is said, to the overshadowing influence of another laboratory connected with the Vienna Academy of Sciences (see Dr. Tietze's "Life of Franz von Hauer," Vienna, 1900).

The Institute possesses extensive geological and mineralogical collections, chiefly from Austrian and Hungarian districts. These are exhibited in twenty-one rooms, some of which are really halls of great architectural beauty. The library contains over 40,000 volumes.

The Reichsanstalt is under the supervision of the Minister for Spiritual and Educational Affairs. Its annual income is $I 8,000$. Its staff numbers twenty persons, twelve of whom are employed in the Geological Survey.

\section{A PARTIAL EXPLANATION OF SOME OF THE PRINCIPAL OCEAN TIDES.}

$A^{T}$ the meeting of the U.S. National Academy of Sciences on April I9, a paper bearing the above title was read by Mr. R. A. Harris, of the United States Coast and Geodetic Survey. An abstract summarising the chief results arrived at has been published by the Academy : the full memoir is to be issued as an Appendix to the Annual Report of the Survey for 1899-1900. The abstract is too short to allow of critical examination of the methods emplcyed in these inquiries, but some of the conclusions stated are very significant and important.

Mr. Harris enunciates the fundamental proposition of his investigation in the following terms: "Considering the actual distribution of land and water, a few computations upon hypothetical cases will suffice to convince one that as a rule the ocean tides, as we know them, are so great that they can be produced only by successive actions of the tidal forces upon oscillating systems, each having, as free period, approximately the period of the forces, and each perfect enough to preserve the general character of its motion during several such periods were the forces to cease their action . . . having once for all constructed a set of force diagrams for the various latitudes, we have only to discover those regions which have a free period of oscillation about equal to the period of the forces, and to then ascertain at what time the particles should be at elongation in their nearly rectilinear paths."

The main idea underlying this proposition is not altogether new, the novelty in the present paper is rather an attempt to locate and define areas which seem to account for the principal ocean tides, due regard being had to the difficulties arising from irregularities in the natural boundaries of such areas where such exist, or from the absence of natural boundaries. Each oscillating area is one of comparatively simple form, of which 